\title{
Correction to: "To Normalize is to Impose a Requirement on an Existence." Why Health Professionals Should Think Twice Before Using the Term "Normal" With Patients
}

\author{
Michael Rost
}

Published online: 23 December 2021

(C) The Author(s) 2021

\section{Correction to: Bioethical Inquiry (2021) 18:389-394 https://doi.org/10.1007/s11673-021-10122-2}

The figure in the opening page of this article was inadvertently published without mention of the artist's copyright. It should have read ' (C) Constantin Becker' below the figure. The original article has been corrected.

Open Access This article is licensed under a Creative Commons Attribution 4.0 International License, which permits use, sharing, adaptation, distribution and reproduction in any medium or format, as long as you give appropriate credit to the original author(s) and the source, provide a link to the Creative Commons licence, and indicate if changes were made. The images or other third party material in this article are included in the article's Creative Commons licence, unless indicated otherwise in a credit line to the material. If material is not included in the article's Creative Commons licence and your intended use is not permitted by statutory regulation or exceeds the permitted use, you will need to obtain permission directly from the copyright holder. To view a copy of this licence, visit http://creativecommons.org/licenses/ by/4.0/.

Publisher's Note Springer Nature remains neutral with regard to jurisdictional claims in published maps and institutional affiliations.
The original article can be found online at https://doi.org/ 10.1007/s11673-021-10122-2

M. Rost $(\bowtie)$

Institute for Biomedical Ethics, University of Basel, Switzerland, Bernoullistr. 28, 4056 Basel, Switzerland e-mail: michael.rost@unibas.ch 